\title{
IMPROVING E-CONSULTATION THROUGH DIGITAL CROWDSOURCING IN UGANDA: A QUANTITATIVE SURVEY
}

\author{
Elizabeth Asianzu \\ School of Computing and Informatics, College of Computing and Information Systems \\ Makerere University, Uganda
}

\begin{abstract}
Information Communication Technology is identified by Uganda government as a key priority sector that will spur socio-economic transformation in the country. Unfortunately, ICT use for e-participation remains a challenge in Uganda. A pertinent issue with e-participation is e-consultation where citizens are expected to use ICT to access and participate in government programs. Despite government's efforts to increase ICT use by integrating it into its operations, minimal progress is recorded as e-consultation level remains low resulting in increase in corruption, lack of transparency and accountability. This study presents the prominent role of digital crowdsourcing in improving e-consultation in Uganda to be implemented using the ten-phase digital crowdsourcing implementation process with social media (Facebook) as a digital crowdsourcing tool. Using National Environmental Management Authority Facebook account to make an open call, randomly sampled participants will be availed self-administered, semi-structured, close-ended online questionnaires to identify the challenges and critical success factors for e-consultation. The participants will engage in the digital crowdsourcing process to address the problem of plastic waste pollution, a major eyesore globally. The major research outcome will be a consistent crowdsourcing implementation process that can be used to improve e-consultation in Uganda.
\end{abstract}

\section{KEYWORDS}

E-consultation, Challenges, Success Factors, Digital Crowdsourcing, Improvement

\section{INTRODUCTION}

Electronic consultation is viewed as the backbone and driver for electronic participation globally, (UN E-government Survey, 2016). E-participation is measured using e-information, e-consultation and e-democracy, (E-government Index, 2018). E-consultation is the engagement of citizens to contribute to and deliberate on public policies and services online (UN, 2018; E-government index, 2018; Sharma, 2014). It has globally grown from $73 \%$ in 2014 to $91 \%$ in 2016, (UN E-government Survey, 2016) with benefits in new policy decisions, regulation and development, (UN E-government Survey, 2016; Wakabi, 2016; Sharma, 2014). UN E-government Survey, (2016) articulates that while it is easier for governments to make progress in e-information stage by providing public information online, it is more challenging to engage in e-consultation and e-democracy yet they are very critical for e-participation.

Uganda suffers the same fate. While the country performs strongest in e-information at $73.5 \%$ resulting from government efforts to integrate Information Communication Technology (ICT) into its operations, there is minimal progress with e-consultation at $26.3 \%$ and zero implementation of e-decision making hence a decline in e-participation index from 0.4915 in 2016 to 0.36 in 2018, (E-government index, 2018). Further, Walugembe, (2018), Ipa, (2018) and Kugonza \& Mukobi, (2015) emphasize the low citizen engagement by the government who sees it as secondary but not a priority thus presenting the urgent need for more investment in e-consultation, (UN E-government Survey, 2016). The current e-consultation strategies include use of websites, the Government-Citizen-Interaction-Center (GCIC) established in 2016, mobile apps, short messaging systems (SMS), social media (facebook and twitter) and putting up calls for public input into legislation, (E-government index, 2018; NDI, 2013). 
These strategies present quite a number of challenges: the GCIC for e-consultation is still in its very early stages so its impact is not measured, only $19.5 \%$ of the Ministries, Departments and Agencies (MDA's) use SMS to collect queries/feedback/suggestions from the public, only 13\% use mobile apps to offer services to citizens, (National IT Survey Report, 2018); government websites are irregularly updated, online information is not provided in reusable formats, websites suffer 'severe lack of information of public interest' and have several accessibility errors particularly to web browsers and special groups like people with disabilities (PWD's). Some government portals put up calls for input into legislation but 'the process lacks consistence' hence some laws are adopted without public input whereas for those with citizen inputs, they are often not adopted into policies/ laws. ICT use is majorly for government-to-government interaction but not government-citizen engagement, (E-government index, 2018; Wakabi, 2016). Further, the e-consultation tools used by government are 'one-way communication channels with queries and comments from citizens receiving no response,' (E-government Index, 2018), a poor type and quality of implementing participation where the tools cannot help citizens become drivers of change, (NDI, 2013). There is no implementation process from the social media guideline by National Information Technology Authority Uganda - NITA-U, (2019).

Uganda performs below the minimum e-consultation utilization level of $30 \%$ compared to other East African countries like Tanzania at $63 \%$ and below the global utilization level of 91\%, (UN E-government survey, 2016). Consequently, there is increased corruption levels, bribery, lack of transparency and accountability by public officials where Uganda is ranked 149 out of 180 of the most corrupt countries in the world, (Transparency International Report, 2018). Further research is needed to examine the challenges of e-consultation, identify the critical success factors and propose a strategy to be implemented to address the problem of low e-consultation. This research contributes to filling these gaps and proposes digital crowdsourcing as a tool to improve e-consultation, (Haltofova, 2018) to be implemented using social media using the 11 step-process model for digital crowdsourcing implementation by Amrollahi (2016) to address the social problem of plastic waste pollution in Uganda.

Plastic waste pollution is a public concern and requires active participation of waste generators in the proper management of waste, (Kodwo et al, 2015). Globally, 79\% of plastics is littered in the environment or accumulated in landfills, (Parker, 2017). In Uganda, plastic waste is the second largest part of solid waste at $37 \%$ to food remains at 38\%. It affects Uganda's largest economy - agriculture which employs $75 \%$ of the population, (Edyegu 2018), generates $25 \%$ of Gross Domestic Product and accounts for 50\% of all exports, (UBOS, 2017). 39,000 tons plastics are discarded in the environment annually due to poor waste disposal habits of the people, (Edyegu, 2018; Mukama et al, 2016) and lack of awareness on proper waste management, (World Bank Group 2017). As a result, 4,700 acres of agricultural land is becoming infertile annually, (Edyegu, 2018) leading to low average agricultural growth of only $2 \%$ annually which is below the desired level, (World Bank, 2018) and lower than the average annual GDP growth rate of 5.2\% targeted under vision 2040 and 'far short of the $6 \%$ growth target for the agricultural sector set by African governments, (MAAIF Report 2016).

With the widespread rise in mobile networks and social media usage globally, (Créquit et al, 2018), the digital crowdsourcing tool can be used to address complex and dynamic societal challenges including plastic waste pollution problem that has adverse effects on agriculture, a major economy in most developing countries. Developing countries will benefit more as Srivastava \& Mostafavi, (2018) state that in 'developing countries, crowdsourcing is still in its budding stage and not much research has been conducted there.' It can improve the e-participation index for the 39 countries that have low index of less than $0.25,36$ countries with middle index of $0.25-0.50$ and 47 countries with high index of $0.50-0.75$ (E-government Index, 2018) who perform very well in e-information stage but very poor in e-consultation.

\section{CHALLENGES \& SUCCESS FACTORS FOR E-CONSULTATION}

Major e-consultation challenges in Uganda include curtailing of internet freedom using laws like Regulations on Interception of Communications Act, 2010; arrests and prosecution of some social media users who comment on matters they deem sensitive; absence of data protection and privacy laws, lack of access and affordability of ICT for the poor, rural and disadvantaged groups like women, PWDs and youth; failure to implement enabling laws and policies, (E-government Index, 2018). Fear of reprisals by citizens whose 
online presence is monitored by government, (Wakabi, 2016). High ICT and internet cost which remains a major hindrance to ICT access and use by citizens, lack of awareness of e-government services (National IT Survey Report, 2018).

Key factors that can increase citizen's uptake of e-consultation include privacy and security of citizens information, (Wakabi, 2016); equal public access and affordability of basic ICT knowledge and infrastructure; citizen trust in both the technology and government, (UN E-government Survey, 2016); age differences between the young and old; education levels; wealth difference between high and low income earners, (Jafarkarimi et al, 2014); citizen involvement in designing e-government services, (National IT survey report, 2018), enforcement of various ICT tools for e-consultation (E-government Index, 2018).

\section{DIGITAL CROWDSOURCING FOR E-CONSULTATION}

Digital crowdsourcing is the use of digital technologies to gather and organize contributions from a multitude of non-professional individuals in order to obtain innovative solutions or products, (Marzano \& Lizut, 2017). It is a successful e-consultation tool, (Haltofova, 2018) that improves e-consultation by fostering participation and making citizens part of the solution, (Zambrano \& Eymann 2014) resulting in transparency and accountability in governments, (Bott, Gigler and Gregor, 2014). The source of control between the organization and the online involved community differentiates digital crowdsourcing from other forms of online participatory culture and user-generated content activities like online problem-solving, (Brabham, 2013). Through the widespread usage of mobile networks and the rise of social media globally, digital crowdsourcing addresses complex global and dynamic challenges, (Créquit et al, 2018). In Uganda, mobile phones and the internet have become integrated into many people's professional, health, business and social lives with mobile phone ownership rate at 70.9\%, (NITA, 2018). With 21, 648, 672 mobile internet subscribers in Uganda, (UCC, 2018), 2,600,000 Facebook subscribers, (Internet World Stats, 2019), digital crowdsourcing has the potential of improving e-consultation in Uganda with ready social media guidelines, however, the guideline lacks an implementation process.

The generic 11 step-process model for digital crowdsourcing implementation presented by Amrollahi (2016) will be adopted in this study excluding the granting award stage since this is not for rewarding the best solution but an outcome-based process. Social media is an important tool used for digital crowdsourcing, (Créquit et al, 2018) and Uganda recognizes it as 'part of the broader efforts to engage citizens' using Twitter and Facebook accounts to engage with its citizens (NITA-U, 2019).

\section{RESEARCH METHODS}

Deductive research approach, a close ally to the philosophy of positivism will be adopted, (Trochim 2006; Shahid, 2014) using quantitative methods, (Yilmaz, 2013 quotes Creswell, 1994); (Eyisi, 2016), cross-sectional descriptive survey (Yilmaz, 2013) using semi-structured, close-ended online questionnaire as the data collection tool tested for validity, (Muhammad et al, 2008) and reliability, (Lakshmi \& Mohideen, 2013). Practical implementation of digital crowdsourcing to improve e-consultation will be achieved using the 11 step generic process by Amrollahi, (2016) as explained:

Conceptual design stage identifies tasks to be performed and these include identifying the challenges and critical success factors for e-consultation and addressing the problem of plastic waste pollution in Uganda under National Environment Authority Management Uganda, (NEMA). Participant selection stage: Facebook subscribers who are 2,600,000 (Internet World Stats, 2019) with 62.36\% subscribers will be used as opposed to Twitter 9.97\%, (Stats Counter, 2019). The technical design stage answers the question of how the digital crowdsourcing should be performed, either using an existing or a new designed platform. In this study, Facebook as an existing tool will be used. In the communication stage, NEMA's Facebook account https://www.facebook.com/NemaUg/, (NITA-U, 2019) will be used to invite as many facebook subscribers as possible through an open call, advertisement media and direct correspondence with subscribers on facebook to participate in the study. According to Morgan's table for sample size presented by The Research Advisors, (2010), for a population of 250,000 to $300,000,000$, the sample size is 384 respondents at 
confidence of $95 \%$ and 5\% margin of error. Therefore, a total of 384 respondents will be randomly selected from the population of 2,600,000 facebook subscribers who will respond to the call and be trained for the task. In the idea/task entry phase, the selected respondents will start to interact through the NEMA facebook account with regard to the specific tasks. In the monitoring phase, the researcher and team from NEMA responsible for managing the facebook account will coordinate the crowd, manage the time for posting tasks, response time and sanction inappropriate entries.

The idea/task revision stage will focus on management of errors from submissions while the submission of entries will be evaluated based on the criteria. Since the crowdsourcing is contribution-based and outcome-based, there will be no rewards to participants hence no granting award phase. In the process evaluation and documentation phase, lessons learnt from this digital crowdsourcing implementation will be documented; future practices will be arranged with plans to retain the participants based on the outcome of the process. In the implementation phase, results from the plastic waste pollution solutions will be presented, analyzed and implemented by the researcher through NEMA.

In conclusion, despite government efforts, e-consultation in Uganda remains low. However, e-consultation presents a huge opportunity for citizen participation in Uganda that will help address key challenges facing the economy. Digital crowdsourcing is expected to improve e-consultation given the high number of internet and facebook subscribers in Uganda. This can only be achieved with a favorable online environment that creates citizen trust in technology and government with properly and carefully implementing digital crowdsourcing using clearly set and realistic objectives and communicating them to all parties concerned.

\section{REFERENCES}

Amrollahi, A. (2016). A Process Model for Crowdsourcing: Insights from the Literature on Implementation, Australasian Conference on Information Systems https://www.researchgate.net/publication/303281353

Barazzetta, S. (2015). Plastic waste management in Africa: lessons from social enterprises, accessed on $1^{\text {st }}$ September, 2018 thru https://www.researchgate.net/publication

Bott, M., Björn-Sören G. \& Gregor, Y. (2014). The Role of Crowdsourcing for Better Governance in Fragile State Contexts. World Bank Publications. http://wbi.worldbank.org/

Brabham, C. D. (2013). Using Crowdsourcing in Government. IBM Center for the Business of Government. Accessed thru www.businessofgovernment.org

Créquit, P., Mansouri, P., Benchoufi, M., Vivot, A. \& Ravaud, P. (2018). Mapping of Crowdsourcing in Health: Systematic Review, J Med Internet Res 2018; 20(5): e187 Vol 20, No 5

Edyegu, D. (2018). Uganda Grapples with Plastic Pollution. American Media Institute, accessed on $15^{\text {th }}$ October 2018 thru https://aminewswire.org/stories/3182/

E-government Index, (2018). State of open e-government index Uganda https://cipesa.org/?wpfb_dl=255

Eyisi, D. (2016). The Usefulness of Qualitative and Quantitative Approaches and Methods in Researching Problem-Solving Ability in Science Education Curriculum. Journal of Education and Practice, Vol.7, No.15, https://files.eric.ed.gov/fulltext/EJ1103224.

Haltofova, B. (2018). Using Crowdsourcing to Support Civic Engagement in Strategic Urban Development Planning: A Case Study of Ostrava, Czech Republic, Journal of Competitiveness, Vol. 10, Issue 1, pp. 85 - 103, June 2018. Internet World Stats, (2019). Internet Users Statistics for Africa, https://www.internetworldstats.com/stats1.htm

Ipa, (2018). Strengthening Local Political Accountability in Uganda. https://www.poverty-action.org/study/

Jafarkarimi, H., Sim, A., Saadatdoost, R. \& Hee M.J. (2014). The Impact of ICT on Reinforcing Citizens' Role in Government Decision Making. International Journal of Emerging Technology and Advanced Engineering Website: www.ijetae.com, Volume 4, Issue 1

Kugonza, S. \& Mukobi, R. (2015). Public participation in services delivery projects in Buikwe District Local Government Uganda. Commonwealth Journal of Local Governance https://epress.lib.uts.edu.au/journals/index.php/cjlg/

Kodwo, M., Kwasi O., Zsófia K., Bernard F., \& Moses Y. M. (2015) Waste Management: Municipal solid waste characterization and quantification as a measure towards effective waste management in Ghana www.elsevier.com/locate/wasman pg15-27 
Lakshmi, S \& Mohideen, M., A. (2013). Issues in Reliability and Validity of Research. International Journal of Management Research and Review Ijmrr/ April 2013/ Volume 3/Issue 4/Article No-8/2752-2758, http://ijmrr.com/admin/upload_data/journal_S_Lakshmi_8apr13mrr.pdf

Marzano, G. \& Lizut, J. (2017). Urban Crowdsourcing: Potential and Challenges. Geographic Information Systems Conference and Exhibition. https://www.researchgate.net/publication/

Ministry of Agriculture, Animal Industry and Fisheries (MAAIF), Report, (2016). Draft Agriculture Sector Strategic Plan 2015/16-2019/20. Accessed on $9^{\text {th }}$ November 2018 thru http://npa.ug/wp-content/uploads/2016/

Mukama, T., Ndejjo R., Musoke, D., Musinguzi, G., Halage, A. A., Carpenter D. O. \& Ssempebwa, J. C. (2016). Practices, Concerns, and Willingness to Participate in Solid Waste Management in Two Urban Slums in Central Uganda. Journal of Environmental and Public Health Volume 2016

Muhammad, B., Muhammad, T., A, and Muhammad, A. (2008). Reliability and Validity of Qualitative and Operational Research Paradigm, Vol. IV No.1, 35-45

National IT Survey Report, (2018). National IT Survey 2017/2018 Report. Accessed thruhttps://www.nita.go.ug/sites/default/files/publications/National\%20IT\%20Survey\%April\%2010th.pdf

National Information Technology Authority Uganda - NITA-U, (2019). Government of Uganda Social Media Guide, https://www.nita.go.ug/sites/default/files/pdf

National Information Technology Authority - NITA, (2018). National Information Technology Survey 2017/2018 Report, https://www.nita.go.ug/sites/default/files/

National Democratic Institute - NDI, (2013). Citizen Participation and Technology. Uganda Country Context: pg 41. https://www.ndi.org/sites/default/files/Citizen-Participation-and-Technology-an-NDI-Study.pdf

Parker, L. (2017). Here's How Much Plastic Trash is Littering the Earth, national geographic society, accessed on $1^{\text {st }}$

September, 2018 thru https://news.nationalgeographic.com

Shahid, N. K. (2014). Qualitative Research Method - Phenomenology. Asian Social Science; Vol. 10, No. 21. https://pdfs.semanticscholar.org/1478/abd02eb468f4639ee9af11c49c9322673957.pdf

Srivastava, P. \& Mostafavi, A. (2018). Challenges and Opportunities of Crowdsourcing and Participatory Planning in Developing Infrastructure Systems of Smart Cities, Infrastructures 2018, 3, 51.

Stats Ccounter, (2019). Social Media Stats Uganda. http://gs.statcounter.com/social-media-stats/all/uganda

The Research Advisors, (2010). Sample Size Table. Accessed thruhttps://shodhganga.inflibnet.ac.in/bitstream/10603/154745/20/20_appendix\%203.pdf

Transparency International Report, (2018). Uganda Corruption Index. https://www.transparency.org/country/UGA

Trochim, W., M., K. (2006). Web Center for Social Research Methods: Research Methods Knowledge Base http://www.socialresearchmethods.net/

Uganda Communications Commission - UCC, (2018). Post, Broadcasting and Telecommunications Market \& Industry Q3 Report, https://www.ucc.co.ug/wp-content/uploads/2017/09/

Uganda Bureau of Statistics (UBOS) (2017). Health status and associated factors, accessed thru https://uganda.unfpa.org

United Nations - UN, (2018). Gearing E-Government to Build Resilient Societies: Preconditions and Enabling Environment.

Annexes, https://publicadministration.un.org/

United Nations (UN) E-government survey, (2018). E-government Development Index: Uganda. https://publicadministration.un.org/egovkb/en-us/

United Nations (UN) E-government Survey, (2016). E-government in support of sustainable development https://books.google.co.ug/books?id=HE88DwAAQBAJ\&pg=PT153\&lpg=PT153\&dq=e-consultation+figures+

Wakabi, W. (2016): Motivating eParticipation in Authoritarian Countries. Örebro Studies in Informatics https://www.diva-portal.org/smash/get/diva2:902111/FULLTEXT04.pdf

Walugembe, D. R. (2018). Engage citizens for better policy implementation, health information scientist. https://www.monitor.co.ug/OpEd/Commentary/

World Bank Group, (2017). Inclusive Innovations: Business Models for Integrated Waste Management, accessed thru https://www.innovationpolicyplatform.org/system/files/4\%20Integrated\%20Waste\%20Manangement.pdf

Yilmaz, K. (2013). Comparison of Quantitative and Qualitative Research Traditions: epistemological, theoretical and methodological differences. European Journal of Education, Vol. 48, No. 2, https://pdfs.semanticscholar.org/f4

Zambrano, R. \& Eymann, S. (2014). Crowdsourcing and Human Development: The Role of Governments. Proceedings of the $8^{\text {th }}$ International Conference on Theory and Practice of Electronic Governance ACM, https://dl.acm.org/citation.cfm?id=269122 